\title{
Building Academic Standards for the Teaching Methods Course (1) at the Faculty of Physical Education, Azhar University According to the Academic National Standards of the Physical Education Sector
}

\author{
El-Sayed Abdel-Aziz Issa ${ }^{1}$ \\ ${ }^{1}$ Assistant Professor, Faculty of Physical Education, Azhar University, Egypt
}

\begin{abstract}
The study aimed to construct academic standards for the teaching methods course (1) in the Faculty of Physical Education at Azhar University according to the National Academic References Standards for the sector of Physical Education. To achieve this aim, the researcher prepared a questionnaire consisted of (25) academic standards which divided into four axes: general skills, knowledge and understanding, practical and professional skills, mental skills, and verified their validity and reliability. The researcher used the descriptive approach because it was appropriate for the nature of the study. The sample of the study consisted of (17) experts from the faculty members specialized in course and teaching methods, and the National Authority for Quality Assurance and Accreditation in the faculties of Physical Education, who were deliberately chosen. The study reached for constructing academic standards for Teaching Methods Course (1) in the Faculty of Physical Education at Al Azhar University according to the National Academic References Standards for the sector of Physical Education. The researcher recommends the use of these academic standards in determining the objectives of the teaching methods course (1), and constructing academic standards for educational programs and other courses in the Faculty of Physical Education at Azhar University according to the National Academic References Standards for the sector of Physical Education.
\end{abstract}

\section{Introduction}

$\mathrm{T}$ The institutions of higher education cared about providing programs and systems to prepare the teacher professionally, academically, culturally and socially. The colleges of physical education have the responsibility of preparing the teacher of physical education and graduating a generation capable of working on clear scientific bases and specific professional skills. Also capable of achieving educational objectives of contemporary society and that's through specialized programs that qualify graduates to carry out tasks and responsibilities that meet the needs of the community on one hand, on the other hand achieve the objectives of the physical education profession. (13:2)

The general objective of the faculties of physical education in all the inputs and the processes of professors, courses, teaching methods, various student activities and evaluation all to prepare the student to become a physical education teacher familiar with all practical and educational aspects and followed all the latest developments in the field of physical education. (15: 103)
In the view of the researcher that in the pursuit of the Faculty of Physical Education at Al-Azhar University to obtain its programs on quality and accreditation must take into count in the design of teaching where the standard national academic for the sector of physical education, and that quality is a global standards of measurement and transition from the culture of minimum performance to perfection, Also consider The future an objective which we seek in specific scientific steps.

Ramzi Abdel Hai (2007) and Halaly El Sherbini (2010) agree that a comprehensive quality system must be implemented within educational institutions so that we can improve performance by providing scientific and educational facilities for students, staff and faculty members. As well as work to link course and courses with the community and the requirements of the labor market, in addition to evaluating all dimensions and elements of the educational system for continuously development and improvement. (7: 108) (1:2)

The course of teaching methods (1) consider one of the course programs in the Department of Course and Teaching Methods of Faculty of physical education, Al- 
Azhar University, which is taught by the students of the third year specialized in course and teaching methods by two lectures weekly, practical lecture and the other theoretical and time of each (120 minutes) The study of this course is the real opportunity for the student teacher in his professional preparation accompanying the period of his field training, where he acquired skills, practices and actual teaching experiences, and considering the course of teaching methods (1) one of the most important elements of physical education teacher preparing programs in the Department of Course and Teaching Methods at the Faculty of Physical Education AL- Azhar University must be included the changes towards the improvement continuously.

through the researcher's acquaintance of what concerns the educational thought of the need to work to improve the student's teaching performance and improve the educational services and learning outcomes and teaching methods transfer from teaching to education to achieve the overall quality, and through his work in the Course Department and Teaching Methods Faculty of Physical Education Al-Azhar University, Doing teaching and evaluation for the student teacher in teaching methods course (1) as one of the courses listed in the Study plan for the department. In addition to viewing the study program of the courses in the department, it is found that there are no academic standards for teaching methods course (1) according to the standard national academic standards for the physical education sector Which has a negative impact on the teaching plan of the course and the lack of sense of its coordination and ranking it in a scientific way, which negatively affected the vision of the teaching staff in the identification and development of learners, as confirms Abdul Salam Mustafa (2000) that from the benefits of setting standards for the course is clarifiy The vision before the teacher which helps him to identify teaching objectives and the experiences of the learners. (11: 146)

As a result of the development witnessed by the Faculty of Physical Education at Al-Azhar University in the pursuit of academic accreditation, which aims to develop the educational systems, study programs and services, And based on the faculty vision and its mission of seeking perfection in the educational process according to quality standards, also through the department of course pursuit and Teaching methods to prepare a distinguished graduate able to compete in the labor market to meet the needs of society in the field of education and that's through the development of his educational programs and educational systems for those programs and the development of the teaching process in the department.
Some studies and educational researches, such as the study of Van Damme, D. (2005)(22) and Sherifa Mohamed (2011)(9) emphasized the importance of looking at quality standards to improve the teaching process of courses.

through viewing the studies and educational research related to the subject of the study The researcher did not find any study that dealt with the construction of academic standards for teaching methods (1) in the faculties of physical education in the light of the national standard academic standards for physical education sector, This is despite the fact that some studies and educational researchers have been taken to develop or evaluate a course in many sports games such as the study of both Amal Abd el maged (2010) (3), Tamer Mahmoud (2011) (5) and Ammar Nasser (2015) (12).

From the above, the study problem appears in the importance of working on preparing an integrated graduate qualified scientifically and professionally Commensurate with the objectives of physical education faculties and the labor market, through preparing a set of educational programs in the Department of Course and Teaching Methods built on scientific, comprehensive and developed Principles and rules according to the standard national academic standards For physical education sector, which all physical education faculties seeks to achieve at the level of the Arab Republic of Egypt. This is why the researcher build academic standards for the course of teaching methods according to scientific bases, clear objectives, and specific scientific content, comprehensive and integrated In accordance with the current needs of the society and the standard national academic standards for physical education sector, modern educational trends and the requirements of the labor market. The present study pursue to answer the following question:

What are the academic standards for teaching methods (1) in the Faculty of Physical Education, Al-Azhar University according to the standard national academic standards for the physical education sector

\section{The importance of studying:}

1 - In response to the recent educational trends in controlling and developing the performance of the teacher according to the standard national academic standards for physical education graduates in accordance with the needs of the labor market.

2. Positive attitudes towards the professional preparation of the student should be a key element in the development of the educational process in accordance with the standard 
national academic standards for the physical education sector.

3- The educational library has been enriched as it is one of the first studies that dealt with the construction of academic standards for teaching methods (1) in the faculties of physical education in accordance with the standard national academic standards for the physical education sector.

\section{Terminology of study:}

\section{Academic Standards:}

Are guidelines formulated in the form of statements agreed upon by a group of experts and drawn from external or national references, which are the minimum skills and knowledge that the graduate must possess after completing his academic program. (15: 17)

\section{The Course:}

Is a collection of topics selected in a particular subject matter, organized in the form of modules for a specific class. (14: 12)

\section{Teaching Methods Course (1):}

Is one of the applied courses in the Department of Course and Teaching Methods taught by third year students at the Faculty of Physical Education, Al-Azhar University in the specialization of course and teaching methods in the first semester divided into A theoretical aspect and a practical aspect two hours a week each, in order to improve the performance of teaching skills for graduates of course and Teaching methods in college.

\section{National Academic Standards:}

The standards that being prepared by the National Authority using specialized experts and representatives of different sectors of the beneficiaries of the educational service, guided by international standards and by preservation of national identity, which represent the minimum required in the educational programs for academic accreditation. (2: 42)

\section{Literature review:}

Several researchers have conducted some studies and educational research related to the current study, including:

1 - Study of Ammar Nasser (2015): 12 which aimed to develop a proposed course for the basic principles of swimming (2) in the Faculty of Physical Education, University of Maysan according to academic standards. The researcher used descriptive method in the survey method. The sample included 12 experts Of specialized faculty members and from The most important objectives of the study are that the most important general objectives of the course of the basic principles of swimming (2) is to provide the student with the ability to place the sciences related to swimming, in order to achieve the unity of knowledge and its integration.

2- The study of Mohammed's Wajdan (2015) (20): That aim to evaluate the first course in swimming sport according to the requirements of the academic standards in the faculties of physical education in the Egyptian universities. The researcher used the descriptive method in the survey method. The sample included 25 experts of specialized faculty members, and from the most important objectives of the study was setting Established proposed to swimming for the first year of Faculty of physical education.

3- Studying Duaa Al-Dardairi (2014) (6): That aimed to determine the teaching competencies required for the teacher's student to determine the methods of teaching handball in light of the academic standards for the quality of the graduates of teaching methods program of physical education. The researcher used the descriptive approach in the survey method and the experimental method. The sample of the study, which reached (43) students of the third year of Faculty of physical education for girls in Alexandria, and one of the most important results of the study that the most important teaching competencies is to evaluate the student taught in the course methods of teaching handball are cognitive, performance, emotional and productivity skills.

4- The study of Muhammad Nabih (2012) (17): That aimed to evaluate the field training for the teaching department in the Faculty of Physical Education Mansoura University in light of the academic standards. The researcher used the descriptive method in the survey method to collect data and reach the results of his study. The study sample contained (150) students from the Faculty of Physical Education for boys in Damietta and Mansoura were chosen randomly. The most important results of the study were that the objectives of the field training were formulated in a behavioral form that could be measured which led to improve the educational objectives in the light of trends of the academic standards.

5 - Mahmoud Mohamed study (2012) (19): which aimed to identify the main axes of the teaching competencies and the most important of the student teacher in the faculties of 
physical education in light of the general specifications of the graduate of Physical Education, which meets the standards of the academic quality, the researcher used the descriptive method, The study sample contained (30) experts of the specialists faculty members, in addition to (45) instructor of the physical education, and from the most important results of the study design a list of axies and teaching competencies of the student teacher in physical education colleges in light of the general specifications of the graduate of physical education according to its standards of academic quality.

6. Chery Henderson \& others, 2006 (21) study: The aim of the study was to develop the teaching method in the light of the quality trends and accreditation in order to obtain academic accreditation at the University of Sydney, Australia. The researchers used the descriptive method. From the most results that the reached is that place a list of quality indicators and determine the levels of achievement for each indicator and then develop it in the light of quality standards and academic accreditation.

\section{Study Procedures:}

\section{The Study method:}

The researcher used the descriptive method and that's to suit the nature and procedures of the study and achieve its objective.

\section{Study and sample society:}

The society of the study composed of faculty members from the course specialists, the teaching methods of physical education and the National Authority for Quality Assurance and Accreditation in the faculties of physical education in Egyptian universities.

The study sample consisted of (17) experts from the faculty members specialized in course and teaching methods of physical education and the National Authority for Quality Assurance and Accreditation in the faculties of physical education in Egyptian universities were chosen in a deliberate manner.

\section{Data collection tools:}

\section{Document Analysis:}

The researcher reviewed the educational literature, studies and educational researches related to the subject of the study, including: (10), (16), (1), (20), (6), (17), (21), (9) Also to view some publications of the National Authority to ensure the quality of education and accreditation, to identify the steps to be followed to achieve the objective of the study.

Communication has been conducted through its analysis to a list of national academic standards for physical education sector, in light of building the academic standards for teaching methods (1) at the Faculty of Physical Education, Al-Azhar University.

\section{Questionnaire:}

Determination the questionnaire axes: A set of axes to be included in the questionnaire for the academic standards of the teaching methods (1), and that's: general skills, knowledge and understanding skills, practical and professional skills, and mental skills.

\section{Initial picture of the questionnaire:}

The researcher developed a set of academic standards for teaching methods (1) in each axis of the questionnaire, guided by the standard national academic standards for the sector of physical education and presented to (10) faculty members from the specialists in the field of course and teaching methods and the National Authority for Quality Assurance and Accreditation In the faculties of physical education. The researcher accepted the academic standards which obtained the approval rate $(80 \%)$ or more.

\section{Validity of the questionnaire:}

The validity of the questionnaire was calculated by means of apparent honesty by presenting it to a sample of (10) experts specialized in course and teaching methods, the National Authority for Quality Assurance and Accreditation in the faculties of Physical Education from the study society and from outside the basic sample. Based on the opinions and observations and the agreed opinions, appropriate modifications, and then presented again after the amendment to the questionnaire in its final form.

\section{Reliability of the questionnaire:}

The researcher calculated the validity of the questionnaire using the method (Test-Retest) and the results are as shown in the following table: 
Table (1)

The Link transactions between the first application and the re-application of the academic standards questionnaire for teaching methods $(1)(n=10)$

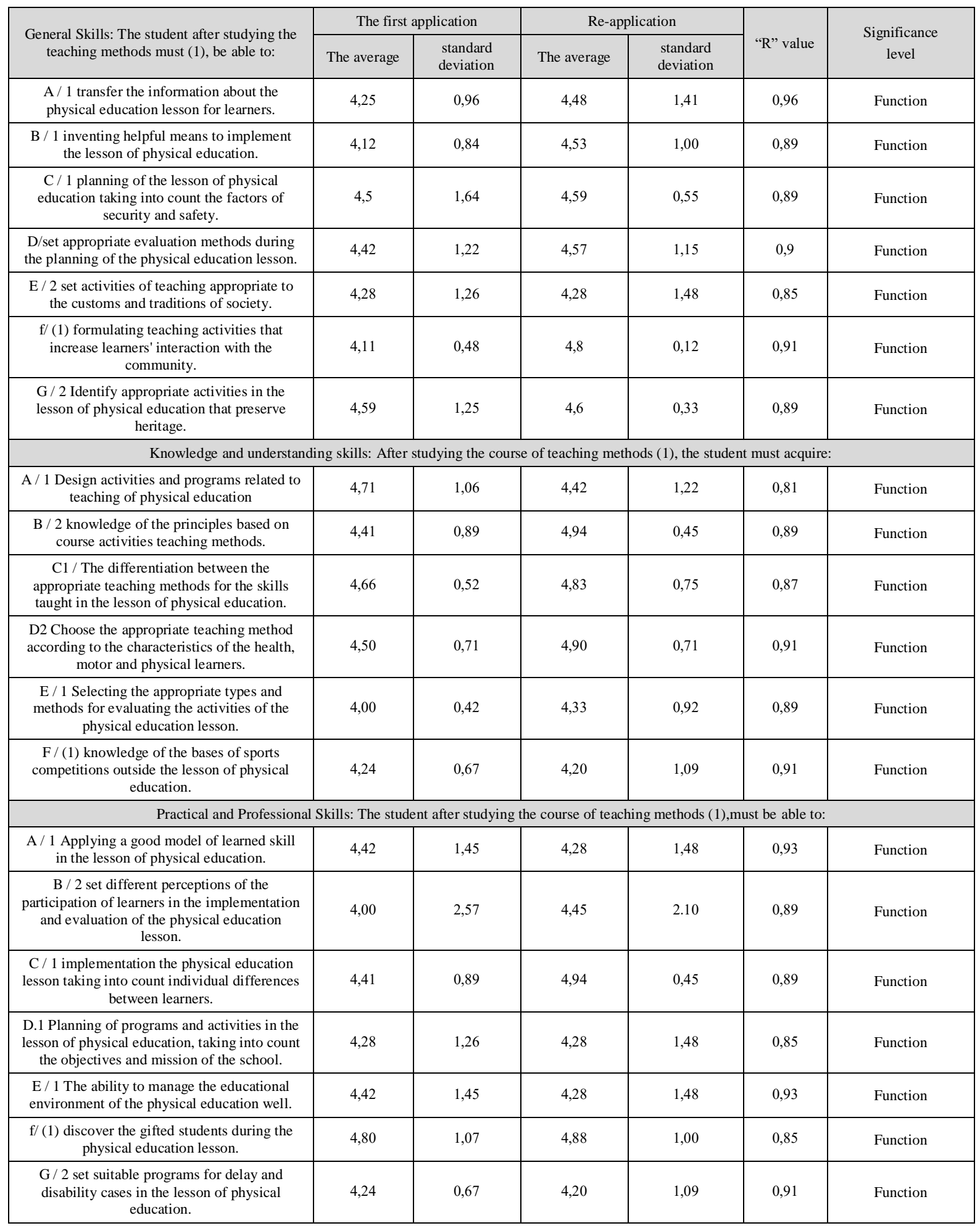


Mental Skills: The student after studying the teaching methods course (1),must be able to:

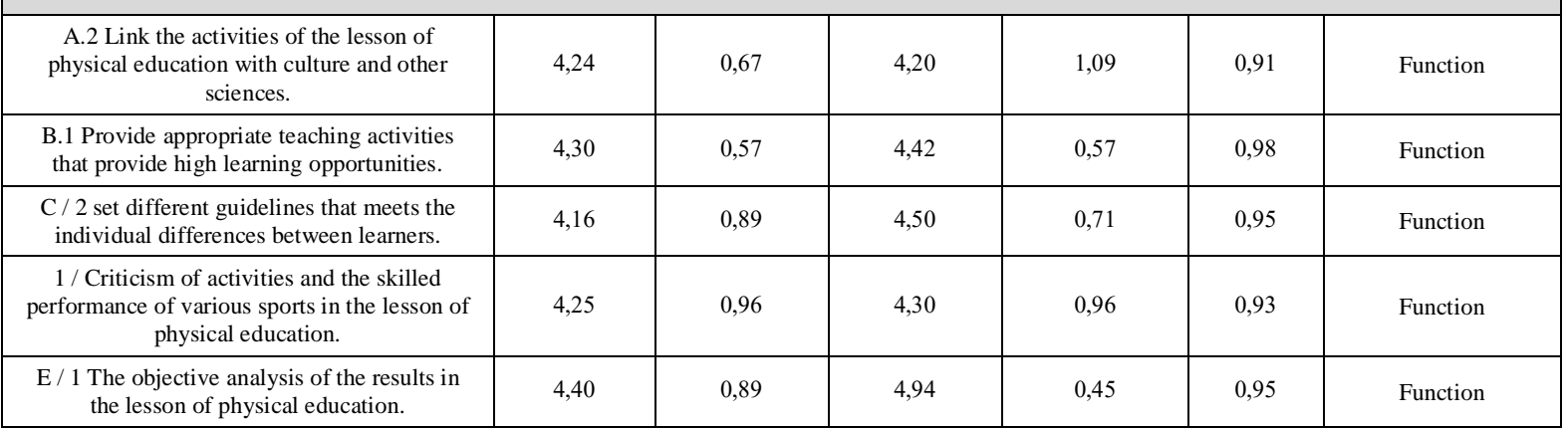

Table (t) value at statistical level $(0.05)=0.63$

Table (1) shows that there is statistically significant relationship between the first application and the reapplication of the questionnaire of the academic criteria for the teaching methods course (1). The correlation coefficient ranged between 0.807 and 0.985 which indicates the reliability of the questionnaire and therefore the results of the study can be trusted.

Apply the questionnaire in its final form:

The questionnaire was completed in its final form, consisting of (25) academic standards distributed on four axes to the members of the basic study sample during the

Table (2) collected and emptied in preparation for the proper statistical treatment.

\section{Presentation and discussion of the study's outcome:}

In this context, the researcher answered the study question by submitting the questionnaire to the study sample from the members of the faculty of specialists in course and teaching methods and the National Authority for Quality Assurance and accreditation in the faculties of physical education. The following table shows this:

Degree and percentage of faculty members' views on academic standards for teaching methods $(1)(n=17)$

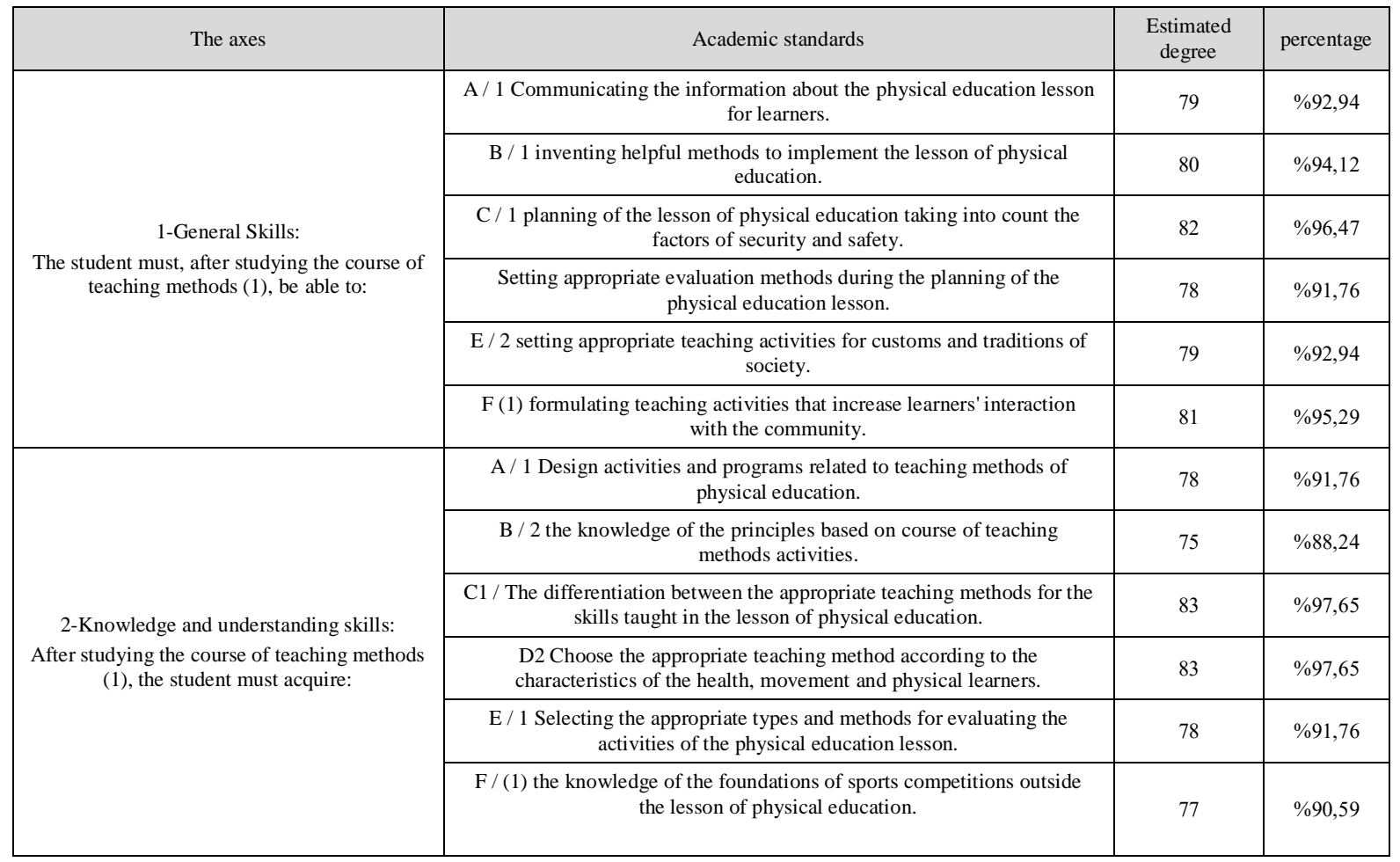




\begin{tabular}{|c|c|c|c|}
\hline \multirow{7}{*}{$\begin{array}{l}\text { 3-Practical and professional skills: } \\
\text { The student must, after studying the course of } \\
\text { teaching methods (1), be able to: }\end{array}$} & $\begin{array}{c}\text { A / } 1 \text { Applying a good model of learned skill in the lesson of physical } \\
\text { education. }\end{array}$ & 79 & $\% 92,94$ \\
\hline & $\begin{array}{l}\text { B / } 2 \text { setting different perceptions of the participation of learners to } \\
\text { implement and evaluate the lesson of physical education. }\end{array}$ & 81 & $\% 95,29$ \\
\hline & $\begin{array}{l}\text { C/ } 1 \text { implementation of the lesson of physical education taking into count } \\
\text { individual differences between learners. }\end{array}$ & 84 & $\% 98,82$ \\
\hline & $\begin{array}{l}\text { D.1 Planning programs and activities in the lesson of physical education, } \\
\text { taking into count the objectives and the vision of the school. }\end{array}$ & 81 & $\% 95,29$ \\
\hline & $\begin{array}{l}\text { E / } 1 \text { The ability to manage the educational environment for physical } \\
\text { education lesson in a good way }\end{array}$ & 77 & $\% 90,59$ \\
\hline & $\begin{array}{l}\text { F (1) the discovery of gifted students during the physical education } \\
\text { course. }\end{array}$ & 85 & $\% 100$ \\
\hline & $\begin{array}{c}\text { G/ } 2 \text { setting suitable programs for delays and impediments in the lesson } \\
\text { of physical education. }\end{array}$ & 77 & $\% 90,59$ \\
\hline \multirow{5}{*}{$\begin{array}{l}\text { 4-Mental Skills: } \\
\text { The student must, after studying the course of } \\
\text { teaching methods (1), be able to: }\end{array}$} & $\begin{array}{l}\text { A. } 2 \text { Link the activities of the lesson of physical education with culture } \\
\text { and other sciences. }\end{array}$ & 79 & $\% 92,94$ \\
\hline & $\begin{array}{l}\text { B.1 Provide appropriate teaching activities that provide high learning } \\
\text { opportunities. }\end{array}$ & 82 & $\% 96,47$ \\
\hline & $\begin{array}{c}\mathrm{C} / 2 \text { setting a variety of guidelines that correspond to the individual } \\
\text { differences between learners. }\end{array}$ & 78 & $\% 91,76$ \\
\hline & $\begin{array}{l}\text { D1 / Criticism of the activities and the skilled performance of various } \\
\text { sports in the lesson of physical education. }\end{array}$ & 79 & $\% 92,94$ \\
\hline & $\begin{array}{c}\text { E / } 1 \text { The objective analysis of the results in the lesson of physical } \\
\text { education. }\end{array}$ & 76 & $\% 89,41$ \\
\hline
\end{tabular}

Table (2) shows that the percentage of the views of the sample study in the general skills of the questionnaire ranged between (90.59\%: 96.47\%) and in the knowledge and understanding axis ranged from (88.24\% to $97.65 \%)$, While the percentage in the field of practical and professional skills ranged from $(90.59 \%$ to $100 \%)$. But the percentage of mental skills ranged from $(89.41 \%$ to 96.47 $\%$.)

It is clear that all the criteria in all the areas of the questionnaire have a high percentage of agreement of the study sample of the faculty members, which indicates their clarification and importance to the teaching methods (1) and its adequacy in all aspects, general, cognitive, practical, professional or mental, also the availability to improve the National Academic Standard for Physical Education Sector.

The researcher worked on covering the academic standards of the course (1) for all aspects of the learner's experience. This is agree with what Amin Al-Khuli and Jamal Al-Shafei (2000) said that the successful course in the physical education is the one that emphasizes the advancement of the learner in all Personal aspects, and in an integrated and balanced manner. (4: 77)

This is confirmed by Zakia Kamel, Nawal Shaltout and Mirvat Khafaja (2002) that the development of the cognitive and intellectual aspect of the learners is necessary and important to improve the vocabulary of the educational process and increase their physical, and cognitive outcomes. (8: 117)
It is also consistent with what Mahmoud Abdel Halim (2006) points out the importance of practical and professional objectives because it is concerned with the acquisition and development of the human movement which is the basis of experience in the field of physical education and the focus of the first interest, through which is achieved the activity of movement, physical and acquire motor skills, fitness and identify the stages of the movement. (18: 108)

In this regard, Mohammed Mujahid (2008) emphasizes that one of the most important characteristics of the criteria is containing all aspects of the educational process from inputs, processes and outputs, as well as all aspects of the personality of the learner, to be implementable on the ground and to be adaptable and in keeping with changing circumstances and variables. Also to be applicable in different educational institutions. He also pointed to the need to set special standards to suit different course within educational institutions. (16:68)

This is confirmed by the results of the study of Sherifa Mohammed (2011) (9) and Tamer Mahmoud (2011) (5) and Wjdan Mohammed (2015) (20) and Muhammad Nabih (2012)

Thus, the question of the study has been answered and its objective is to establish academic standards for teaching methods (1) at the Faculty of Physical Education, AlAzhar University, in accordance with the national academic standards for the physical education sector. 


\section{Recommendations and proposals:}

1- Using academic standards for the teaching methods (1) which the study reached when setting the objectives of the course.

2- Building academic standards for educational programs and other courses at the Faculty of Physical Education, AlAzhar University in accordance with the national academic standards for the physical education sector.

3- Using academic standards for the physical education sector in evaluating scientific course of theoretical and applied materials in the faculties of physical education.

4- Building unified course in light of the national academic standards for physical education sector for all subjects in the faculties and departments of physical education, which accordance with the requirements of professional work and the needs of the community and the labor market.

\section{References}

1- Al-Hilaly Al-Sherbini: Quality and Accreditation in Higher Education Institutions, Mansoura, Library Trendy 2010.

2- The National Authority for Quality Assurance of Education and Accreditation: Academic Standards for the physical Education Sector, Cairo, Authority publications, 2008.

3- Amal Abdul Majid: An analytical study to evaluate the course of physical education for artistic gymnastics for the primary stage, "Unpublished $\mathrm{PhD}$ thesis", Faculty of Physical Education, Helwan University, 2010.

4- Amin Al-Kholy and Jamal Al-Shafei: Course of Physical Education, Cairo, Arab Thought House, 2000.

5- Tamer Mahmoud: A proposed plan for the development of handball course in the faculties of physical education in the Republic of Egypt Arabic in light of the overall quality standards, "unpublished doctoral thesis", Faculty of Physical Education, Mansoura University, 2011.

6- Duaa Aldderiri: Evaluation of the teaching competencies required for the student teacher of the course methods of teaching ball Hand in light of the academic standards for the quality of the graduates of the road program Teaching Physical Education in Alexandria, Assiut Journal of Education Sciences and Arts Mathematics, p. 39, c1, Faculty of Physical Education, Assiut University, 2014.
7- Ramzi Abdel Hay: Evaluation of the performance of university administration in the light of total quality management, Alexandria, Dar Al Wafaa, 2007.

8- Zakia Kamel, Nawal Shaltout and Mirvat Khafaja: Methods of Teaching in Physical Education Fundamentals In Teaching Physical Education, Alexandria, Library of Radiation Art, 2002.

9- Sherifa Mohamed: Analytical study of the reality of school sports in light of the quality standards of education and accreditation Education, "Unpublished Doctoral Thesis", Faculty of Physical Education, University Helwan, 2011.

10- Abdul Rady Hassan: the application of the quality system of education and accreditation for the development of university education and before University, Cairo, Arab Thought House, 2008.

11- Abdel Salam Mustafa: Fundamentals of Teaching, Cairo, Arab Thought House, 2000.

12- Ammar Nasser: proposed course for swimming Faculty of Physical Education, University of Maysan in light of the standards Quality and Accreditation, "Unpublished Master Thesis", Faculty of Physical Education Mansoura University, 2015.

13- Laila Zahran: scientific and technical assets "course and programs" in Physical Education, Cairo, Dar Zahran Publishing \& Distribution, 2001.

14- Scientific and technical assets for building course and programs in physical education, I 4, Cairo, Dar Zahran Publishing and Distribution, 2006.

15- Mohammed Zaghloul and Makarem Abu Harja: Course of physical education oriented value in the face of Reflections of the Era of Globalization, Cairo, the Book Center for Publishing, 2005.

16- Mohamed Mujahid: Culture of Standards and Quality in Education, Cairo, University House, 2008.

17- Mohammed Nabih: Evaluation of the field training course for the Teaching Division in the faculties of Physical Education Mansoura University in light of academic standards, "Master's Thesi Mansoura, Faculty of Physical Education, Mansoura University, 2012.

18- Mahmoud Abdel Halim: Dynamics of teaching physical education, Cairo, the book center for publishing, 2006.

19- Mahmoud Mohamed: Qualifications of the student teaching teacher according to standard academic quality 
standards Scientific Journal of Physical Education and Sports Sciences, P19, C2, Faculty of Education University of Mansoura, 2012.

20- Mohamed Wajdan: Evaluation study of the swimming course of the first group in the faculties of physical education in universities Egyptian standard academic standards, "unpublished doctoral thesis", Faculty of Physical Education, Mansoura University, 2015.
21- Cherry Henderson\& others: Benchmarking Learning and Teaching, developing a method Quality Assurance, Education Journal, Volume (14), Issue (2), Emerald Group publishing Limited, UK, 2006.

22- Van Damme, D.: Standards and Indicators in Institutional and Programmer Accreditation in higher, In Uneesco studies on higher Education, indicators for Institutional and Programmer Accreditation in higher, Tertiary Education Bucharest, 2005. 